\title{
The moderating role of board gender diversity between power-based corporate governance and tax aggressiveness
}

\author{
Farzan Yahya ${ }^{1, *} \cdot$ Abdul Manan ${ }^{1} \bullet$ \\ Muhammad Wasim Jan Khan' ${ }^{2}$ Muhammad Sadiq Hashmi ${ }^{1}$ \\ ${ }^{1}$ Department of Business Administration, Institute of Southern Punjab, Multan, Pakistan \\ ${ }^{2}$ Department of Management Sciences, University College of Zhob, BUITEMS \\ (BUITEMS Sub-Campus Zhob) Balochistan, Pakistan
}

Received: 7 April 2020

Revised: 6 July 2020

Accepted: 29 July 2020

\begin{abstract}
The purpose of this study is to explore the moderating effect of board gender diversity on the relationship between power-based corporate governance (CEO power and concentrated ownership) and tax aggressiveness. The sample of this study is based on 2,071 firm-year observations over the period 2010 to 2018. We employed two-step GMM estimations to account for endogeneity and other statistical biases. The results show that CEO power increases the likelihood of tax aggressiveness while the link between the large controlling shareholders and tax-avoidance activities is not statistically significant. Lastly, the findings suggest that powerful CEOs manipulate female directors to promote tax aggressiveness behavior.
\end{abstract}

Keywords: CEO power; ownership concentration; gender diversity; tax aggressiveness JEL Classification Codes: M120, G3, G38, M410

\section{Introduction}

Corporate taxes are essential for civilized society and government stability to generate sustainable sources of revenue for social goods, especially in developing countries. There are practical and equitable reasons to pay corporate taxes as businesses also gain benefits from the enriched infrastructure of a country (Hilling \& Ostas, 2017). However, corporations may opt for several legal or illegal ways to diminish their tax liability. Although tax aggressiveness is a legal way of increasing after-tax income, it may create agency conflicts and spillover detrimental effect on the national economy (Lanis et al., 2017). A wide range of studies associated excessive tax aggressiveness with management and shareholders' motives (Armstrong et al., 2019; Halioui et al., 2016; Lanis et al., 2017). Corporate tax aggressiveness creates agency conflicts due to misalignment between the managers and shareholders' interest

\footnotetext{
* Corresponding author. E-mail: farzan.yahya@yahoo.com.

Citation: Yahya, F., Manan, A., Jan Khan, M. W., and Hashmi, M. S. (2021) The moderating role of board gender diversity between power-based corporate governance and tax aggressiveness, Economics and Business Letters, 10(2), 140-147.
}

DOI: 10.17811/ebl.10.2.2021.140-147 
concerning tax risks. Self-interested managers or directors may expropriate corporate resources for their private interests by structuring the complexity of the firm's decisions (Kubick, \& Lockhart, 2016).

This study contributes to the academic literature related to tax aggressiveness and its determinants especially in the context of an emerging economy like Pakistan. According to our best knowledge, this study is the first attempt to explore the drivers of tax aggressiveness in the corporate settings of Pakistan. The government is struggling to adjust income distribution in the favor of poorest income quintiles of Pakistan due to a narrow tax base. Although corporate taxes were reduced after certain reforms, the majority of the firms do not report a positive tax liability (Feltenstein et al., 2017). Therefore, there is a dire need to address and comprehend the phenomenon of corporate tax aggressiveness in the Pakistani capital market.

Since corporate governance mechanisms explain a large proportion of variation in tax aggressive decisions (Kovermann, \& Velte, 2019), we consider power-oriented corporate governance mechanisms to empirically test their effect on tax aggressiveness. Primary agency conflicts may arise when powerful CEOs try to set their compensation arrangements by manipulating board decisions against shareholders' interests (Ding et al., 2015; Guo et al., 2015; Kubick, \& Masli, 2016). Likewise, considering tax avoidance as an alternative investment opportunity, CEOs entrenchment manipulate stakeholders of the firm by exploiting free cash flows which they use for earnings management and tax aggressiveness (Wang et al., 2018). Thus, studies found that a greater level of tax aggressiveness in the presence of overconfident and powerful CEOs (Kubick \& Lockhart, 2017). Following these shreds of evidence, our first objective is to investigate the effect of CEO power on tax aggressiveness.

Owner concentration is the second power-oriented mechanism in this study. Concentrated ownership is an indicator of weak investor protection as it may also influence the firm's important decisions to extract rents (Ying et al., 2017). Owing to their control of decisionmaking and involvement in managerial activities, agency conflicts between majority and minority shareholders may arise (Desai \& Dharmapala, 2008). Therefore, in line with the entrenchment effect of agency perspective, we argue that concentrated shareholders commit tax manipulation activities to expropriate minority owners. Recent studies also found a positive effect of ownership concentration on the higher level of tax aggressiveness (Mafrolla, \& D'Amico, 2016; Ying et al., 2017). Accordingly, our second objective is to examine if ownership concentration promotes the tax aggressiveness behavior of a firm.

Lastly, we incorporate board gender diversity in our empirical model as a monitoring mechanism. In support of women on board, prior studies argued that female directors effectively monitor the opportunistic behavior of managers and make continuous efforts to improve financial reporting quality by identifying transactional errors in financial statements (Adams \& Ferreira, 2009). Presence of women on board enhance economic outcomes (RegueraAlvarado et al., 2017), higher sustainability disclosure (Ben-Amar et al., 2017), choose wellreputed external auditors (Lai et al., 2017) and pay more dividends to the shareholders (Ye et al., 2019) to restrict managers from extracting rents from free cash flows. Overall, female directors promote strong corporate governance practices in an organization (Melón-Izco et al., 2020). Accordingly, a negative link between female directorship and tax aggressiveness is evident in previous studies (Lanis et al., 2015; Richardson et al., 2016). Under the aforementioned theoretical justification of effective female directors' monitoring capability, our third objective is to investigate the moderating effect of board gender diversity between power-based corporate mechanisms (CEO power and ownership concentration) and tax aggressiveness.

This study provides certain contributions to the existing literature. First, we explore the relationship between corporate governance mechanisms and tax aggressiveness literature in the Pakistani context where tax compliance is the serious concern of policymakers. Second, this 
study is the first attempt to evaluate the role of board gender diversity in influencing powerful CEOs and shareholders who manipulate tax planning for their benefits. Discrimination and underrepresentation of women in the workplace is also a significant hurdle in their career advancement as the cultural norms in Pakistan compel them to abide by the reputable femininity ideologies (Ansari, 2016). Thus, the study highlights their role in curbing organizational malpractices in a male dominant society to validate the effectiveness of corporate governance in Pakistan.

\section{Research methodology}

\subsection{Data and sample size}

Initially, we selected 296 non-financial firms from different sectors ${ }^{1}$ over the period 2010 to 2018. However, after excluding firms with extreme ${ }^{2}$ and missing values, a final unbalanced panel data of 2,071 firm-year observations are used in the analysis. Financial firms differ from non-financial firms in terms of financial reporting and financial leverage due to which they are not included in the sample. Hand collected panel-data from annual reports was utilized to measure the variables of the study. Descriptive statistics of the data are given in Table 1.

\subsection{Measurement of the variables}

Tax aggressiveness is the dependent variable of the study. Several measures of tax aggressiveness are developed in prior studies, however, effective tax rate (ETR) is the most commonly used measure. Nonetheless, ETR (measured by the tax liability divided by income) has certain limitations. Traditional ETR measures do not account for temporary book-tax differences as a lower level of tax expense in the current year is offset by a higher level of deferred tax expense. On the other hand, Frank et al. (2009) developed a more comprehensive model using discretionary permanent differences (DTAX). They regressed total permanent boot-tax differences on non-discretionary items. Following the model of Frank et al. (2009) was used to evaluate the residuals from the annual cross-sectional regression:

$$
\begin{gathered}
\text { PERMDIFF }_{i t}=\alpha_{0}+\alpha_{1} \text { INTANG }_{i t}+\alpha_{2} \text { UNCON }_{i t}+\alpha_{3} \text { MIit }+\alpha_{4} \text { CSTE }_{i t}+\alpha_{5} \Delta N O L_{i t} \\
+\alpha_{6} L_{\text {LAGPERM }}+\varepsilon_{i t}
\end{gathered}
$$

Where PERMDIFFit = Pre-tax book income $(\mathrm{PI})$ less minority interest (MII) less an estimate of taxable income, where taxable income is computed as the sum of federal tax expense (TXFD) and foreign tax expense (TXFO) grossed up by the statutory rate.

Table 1. Descriptive statistics.

\begin{tabular}{lrrrr}
\hline \hline Variable & Mean & St. Deviation & Minimum & Maximum \\
\hline DTAX & 0.027 & 0.567 & -0.086 & 0.625 \\
CEO Power & 0.109 & 0.116 & 0.001 & 0.659 \\
Ownership concentration & 0.729 & 0.187 & 0.292 & 0.997 \\
Board Gender Diversity & 0.070 & 0.096 & 0.000 & 0.308 \\
Return on Asset & 0.126 & 0.116 & -0.196 & 0.679 \\
Financial Leverage & 2.349 & 6.346 & 0.004 & 67.079 \\
Firm Size & 24.118 & 1.358 & 20.905 & 27.803 \\
Board Size & 8.712 & 1.942 & 4.000 & 15.000 \\
\hline \hline
\end{tabular}

\footnotetext{
${ }^{1}$ Major sectors include Automobile Assembler, Cement, Chemical, Engineering, Fertilizer, Food and personal care products, Leather and Tanneries, Oil \& Gas, Paper and Board, Pharmaceutical, Power Generation and distribution, Sugar refineries, Technology and Communication, Textile, Tobacco and Transport

${ }^{2}$ Cook's distance and leverage values were used to identify and eliminate outliers.
} 
INTANit $=$ Goodwill and other intangibles $($ INTAN), UNCONit $=$ Income $($ loss $)$ reported under the equity method (UNCON), CSTEit = Income (loss) attributable to minority interest (MII), MIit = Current state income tax expense (TXS); $\Delta$ NOLit $=$ Change in net operating loss carry forwards $($ TLCF), LAGPERMit = One-year lagged PERMDIFF.

To measure CEO Power, prior studies suggested using pay slice (the extent to which CEOs extract rents). CEO Pay Slice is the percentage of CEO compensation compared to the compensation of the top five executives of the company (Bebchuk et al., 2011). However, the disclosure policy in the Pakistan capital market is weak due to which the data of the top five executives are not available for every company. We modified the proxy of the CEO pay slice based on available data. To measure CEO power, we considered the percentage of the total compensation of paid to the executives captured by the CEO.

The percentage of shares held by the top 5 stockholders was used as a proxy for ownership concentration and the percentage of women directors on board was used to reflect board gender diversity. Furthermore, several control variables are incorporated into the empirical model to mitigate the omitted bias. Based on the firm-specific characteristics, the behavior of firms toward tax aggressiveness could be different. Large firms (measured by the natural log of the total sales) are more likely to involve themselves in tax aggressiveness (Hoi et al., 2013). Firms with higher financial leverage (measured by debt-to-equity ratio) are more efficient in reducing tax expenses (Gupta \& Newberry, 1997). Profitable firms (measured by ROA) generally have higher ETRs (Wilson, 2009) and large board size (natural log of total board members) decreases the monitoring efficiency of the board of directors to restrict managers from rent extraction (Jensen, 1993).

\subsection{Model specification}

To investigate the effect of CEO power and ownership concentration on tax aggressiveness along with the moderating role of board gender diversity, the following static model was developed:

$$
\begin{gathered}
T A X A_{i t}=\alpha+\beta_{1} O W C_{i t}+\beta_{2} C E O P_{i t}+\beta_{3} B G D_{i t}+\beta_{4} O W C^{*} B G D_{i t}+\beta_{5} C E O P^{*} B G D_{i t}+ \\
\beta_{6} \text { FSIZE }_{i t}+\beta_{7} R_{R O A_{i t}}+\beta_{8} F I N L_{i t}+\beta_{9} B S I Z E_{i t}+\mu_{i}+\eta_{t}+\varepsilon_{i t}
\end{gathered}
$$

Where TAXA is tax aggressiveness, OWC is ownership concentration, BGD is board gender diversity, OWC*BGD is the interaction of ownership concentration with board gender diversity, CEOP*BGD is the interaction of CEO power with board gender diversity, FSIZE is the firm size, ROA is the return on equity, FINL is the financial leverage, BSIZE is the board size, $\eta_{\mathrm{t}}$ is the time-specific effects, $\mu_{\mathrm{i}}$ is the unobserved industry-specific effects and error term.

Previous studies argued that the relationship between corporate governance and tax aggressiveness is subject to endogeneity bias. There is a possibility that firms who are more tax aggressive may hire power CEOs or female directors. Furthermore, the issue of omitted bias may also occur due to endogeneity bias. In this case, the static model such as ordinary least square (OLS), fixed-effect, or Prais-Wintson models produces biased estimates. In this scenario, a dynamic model such as system-GMM is more reliable (Ullah et al., 2018). However, before analyzing a dynamic panel model, we assume that CEO power or board gender diversity may influence tax manipulation decisions due to the presence of high debt or large board size. We considered their lagged values as instruments and level forms as controlled variables. Overidentifying restriction of standard Hansen test was evaluated to identify the existence of serial correlation and strength of instruments.

$$
\begin{gathered}
\text { TAXA }_{\text {it }}=\alpha+\beta_{1} \text { TAXA }_{i, t-1}+\beta_{2} \text { OWC }_{\text {it }}+\beta_{3} \text { CEOP }_{\text {it }}+\beta_{4} \text { BGD }_{i t}+\beta_{5} \text { OWC }^{*} \text { BGD }_{i t}+ \\
\beta_{6} \text { CEOP }^{*} \text { BGD }_{\text {it }}+\beta_{7} \text { FSIZE }_{i t}+\beta_{8} \text { ROA }_{i t}+\beta_{9} \text { FINLL }_{i t}+\beta_{10} \text { BSIZE }_{i t}+\mu_{\mathrm{i}}+\eta_{\mathrm{t}}+\varepsilon_{i t}
\end{gathered}
$$


Table 2. Regression Results.

\begin{tabular}{lrrr}
\hline \hline & Fixed-Effect & Diff-GMM & System GMM \\
\hline Lagged DTAX & $0.039^{*}(0.058)$ & $0.016^{* *}(0.090)$ & $-0.026^{* *}(0.023)$ \\
CEO Power & $2.714(1.756)$ & $0.679^{*}(0.944)$ & $0.034^{* * *}(0.966)$ \\
Ownership Concentration & $-0.888(1.496)$ & $-0.480(0.947)$ & $-0.206(0.364)$ \\
Board Gender Diversity & $-4.160^{*}(5.110)$ & $-1.059^{* *}(1.999)$ & $-1.363^{*}(0.995)$ \\
CEO Power $\times$ BGD & $0.242(0.170)$ & $0.051^{*}(0.069)$ & $0.017 *(0.053)$ \\
Ownership $\times$ BGD & $0.159(0.172)$ & $0.056(0.131)$ & $0.030(0.070)$ \\
Return on Assets & $-1.663(1.367)$ & $-0.540^{* *}(0.849)$ & $-0.714 * *(0.775)$ \\
Financial Leverage & $-0.056(0.026)$ & $-0.037(0.019)$ & $-0.026(0.013)$ \\
Firm Size & $-0.221(0.249)$ & $-0.016(0.186)$ & $-0.052(0.065)$ \\
Board Size & $0.964(0.760)$ & $0.794(0.711)$ & $0.529(0.344)$ \\
Constant & $-7.177(6.889)$ & $3.811(3.027)$ & $-2.289(2.140)$ \\
Year Dummies & Yes & Yes & Yes \\
Industry Dummies & 0.006 & Yes & Yes \\
Wooldridge test for AR(1) & & & 0.525 \\
Hansen J-test & & 0.024 & 0.439 \\
Arellano-Bond test for AR(1) & & 0.803 & 0.018 \\
Arellano-Bond test for AR(2) & & & 0.836 \\
\hline \hline
\end{tabular}

Notes: Values in parenthesis are the robust standard errors. Hansen J-test refers to the over-identification test for the restrictions in GMM estimation. The AR1 test is the Arellano-Bond test for the existence of the first-order autocorrelation in first differences. The AR2 test is the Arellano-Bond test for the existence of the second-order autocorrelation in first differences. *, **, and $* * *$ indicate significance at the $10 \%, 5 \%$, and $1 \%$ levels, respectively.

In the case of endogeneity bias, the error term is generally correlated with explanatory variables, and lagged-value of dependent variable show significant association with the dependent variable. This issue can be mitigated with a dynamic panel GMM model (Blundell \& Bond, 1998).

\section{Results and discussion}

Table 2 shows the results of the fixed effect, difference GMM, and system GMM estimations. Owing to the statistical significance of previous year tax aggressiveness with the current year's tax aggressiveness, we assumed that the model is subject to endogeneity. Thus, the GMM model is preferable in this context as the OLS estimator is upwardly biased while fixed-effect estimations are downwardly biases. Although we analyzed the difference GMM estimator, system GMM is designed to have superior finite sample properties (Blundell \& Bond, 1998). Before analyzing the main results, we fulfilled the panel unit root restriction using the method of Im et al. (2003) which is a less restrictive and more powerful unit root test. Non-stationary variables (ROA and financial leverage) were transformed into growth form.

Results of two-step system GMM shows that CEO Power was positively associated with tax aggressiveness $(\beta=0.034, p=0.008)$ while no significant effect of ownership concentration was found $(\beta=-0.206, p=0.517)$. On the other hand, female directors decrease the likelihood of tax aggressiveness in a firm $(\beta=-1.363, p=0.053)$. Nonetheless, the interaction of female directors with CEO power enhances the likelihood of tax aggressiveness $(\beta=0.017, p=0.062)$. Table 2 also shows that there is no significant moderating effect of board gender diversity on the relationship between ownership concentration and tax aggressiveness.

Our estimations are partially consistent with agency perspective, powerful CEOs who are capable of setting their compensation may elevate the tax aggressiveness of the firm. This argument is consistent with previous studies that powerful CEOs consider aggressive tax planning as an alternative investment opportunity and a mechanism for gaining personal interests (Ding et al., 2015; Kubick, \& Masli, 2016; Wang et al., 2018). Nonetheless, female 
directors act as an efficient monitor to restrict tax aggressiveness. Consistent with the prior studies, we also argue that female director improves financial reporting quality (Adams \& Ferreira, 2009) and promote good governance practices in an organization (Melón-Izco et al., 2020) through which they curb tax planning motives (Lanis et al., 2015; Richardson et al., 2016). However, the monitoring role of female directors in the presence of power CEOs is not very efficient over restricting aggressive tax planning. We argue that powerful CEOs either manipulate or repress women on board to extract rents in a male dominant society like Pakistan. Consistent with prior studies, our estimations confirm the weak corporate governance structures in Pakistan (Yahya, \& Ghazali, 2017).

\section{Conclusion}

This study aims to examine the monitoring role of board gender diversity on the relationship between CEO power, ownership concentration, and tax aggressiveness. We find partial support of agency theory in the context of the Pakistani capital market that powerful CEOs enhance the likelihood of tax aggressiveness while female directors make efforts to c such activities. However, the male dominant society of Pakistan may curb their rights and powers to minimize tax planning activities when CEOs are powerful. We also find that the direct effect of ownership concentration on tax aggressiveness is not evident and there is a possibility that powerful shareholders influence a firm's decisions by empowering CEOs.

We acknowledge that this study is not free from limitations. We have utilized only one proxy to measure tax aggressiveness while better measurements are available in the existing literature which may provide different estimations. Additionally, limited corporate governance mechanisms are considered in the study. Future studies may incorporate other ownership types and behavioral variables to generate more generalized and robust estimates. To further mitigate the corporate tax avoidance behavior, we recommend policymakers to further reduce corporate taxes. Although the government has made efforts to facilitate the industries over the period, the corporate tax rate of Pakistan is still higher than most of the Asian countries. Furthermore, likewise most of the western countries, Securities and Exchange Commission of Pakistan (SECP) should also enforce listed firms to maintain the minimum level of women representation on their boards.

\section{Acknowledgement}

We would like to thank the editor and reviewers for their constructive comments that substantially improved our manuscript.

\section{References}

Adams, R. B., and Ferreira, D. (2009) Women in the boardroom and their impact on governance and performance, Journal of financial economics, 94(2), 291-309.

Ansari, N. (2016) Respectable femininity: a significant panel of glass ceiling for career women, Gender in Management: An International Journal. 31(8), 528-541.

Armstrong, C. S., Glaeser, S., and Kepler, J. D. (2019) Strategic reactions in corporate tax planning, Journal of Accounting and Economics, 68(1), 101232.

Bebchuk, L. A., Cremers, K. M., and Peyer, U. C. (2011) The CEO pay slice, Journal of Financial Economics, 102(1), 199-221.

Ben-Amar, W., Chang, M., and McIlkenny, P. (2017) Board gender diversity and corporate response to sustainability initiatives: Evidence from the carbon disclosure project, Journal of Business Ethics, 142(2), 369-383.

Blundell, R., and Bond, S. (1998) Initial conditions and moment restrictions in dynamic panel data models, Journal of Econometrics, 87(1), 115-143. 
Desai, M. A., and Dharmapala, D. (2008) Tax and corporate governance: an economic approach, in Tax and Corporate Governance (pp. 13-30), Springer, Berlin, Heidelberg.

Ding, S., Jia, C., Wilson, C., and Wu, Z. (2015) Political connections and agency conflicts: the roles of owner and manager political influence on executive compensation, Review of Quantitative Finance and Accounting, 45(2), 407-434.

Feltenstein, A., Mejia-Mantilla, C., Newhouse, D., and Sedrakyan, G. (2017) The poverty implications of alternative tax reforms: Results from a numerical application to Pakistan, The World Bank.

Frank, M. M., Lynch, L. J., and Rego, S. O. (2009) Tax reporting aggressiveness and its relation to aggressive financial reporting, The Accounting Review, 84(2), 467-496.

Guo, L., Jalal, A., and Khaksari, S. (2015) Bank executive compensation structure, risk taking and the financial crisis, Review of Quantitative Finance and Accounting, 45(3), 609-639.

Gupta, S., and Newberry, K. (1997) Determinants of the variability in corporate effective tax rates: Evidence from longitudinal data, Journal of Accounting and Public Policy, 16(1), 134.

Halioui, K., Neifar, S., and Abdelaziz, F. B. (2016) Corporate governance, CEO compensation and tax aggressiveness. Review of Accounting and Finance, 15(4), 445-462

Hilling, A., and Ostas, D. T. (2017) Corporate taxation and social responsibility (Vol. 1), Wolters Kluwer.

Hoi, C. K., Wu, Q., and Zhang, H. (2013) Is corporate social responsibility (CSR) associated with tax avoidance? Evidence from irresponsible CSR activities, The Accounting Review, 88(6), 2025-2059.

Jensen, M. C. (1993) The modern industrial revolution, exit, and the failure of internal control systems, The Journal of Finance, 48(3), 831-880.

Kovermann, J., and Velte, P. (2019) The impact of corporate governance on corporate tax avoidance-A literature review, Journal of International Accounting, Auditing and Taxation, 36, 100270.

Kubick, T. R., and Lockhart, G. B. (2016) Do external labor market incentives motivate CEOs to adopt more aggressive corporate tax reporting preferences?, Journal of Corporate Finance, 36, 255-277.

Kubick, T. R., and Lockhart, G. B. (2017) Overconfidence, CEO awards, and corporate tax aggressiveness, Journal of Business Finance \& Accounting, 44(5-6), 728-754.

Kubick, T. R., and Masli, A. N. (2016) Firm-level tournament incentives and corporate tax aggressiveness, Journal of Accounting and Public Policy, 35(1), 66-83.

Lai, K. M., Srinidhi, B., Gul, F. A., and Tsui, J. S. (2017) Board gender diversity, auditor fees, and auditor choice, Contemporary Accounting Research, 34(3), 1681-1714.

Lanis, R., Richardson, G., and Taylor, G. (2017) Board of director gender and corporate tax aggressiveness: An empirical analysis, Journal of Business Ethics, 144(3), 577-596.

Mafrolla, E., and D'Amico, E. (2016) Tax aggressiveness in family firms and the non-linear entrenchment effect, Journal of Family Business Strategy, 7(3), 178-184.

Melón-Izco, Á., Ruiz-Cabestre, F. J., and Ruiz-Olalla, M. C. (2020) Diversity in the board of directors and good governance practices, Economics and Business Letters, 9(2), 97-105.

Reguera-Alvarado, N., de Fuentes, P., and Laffarga, J. (2017) Does board gender diversity influence financial performance? Evidence from Spain, Journal of Business Ethics, 141(2), 337-350.

Richardson, G., Taylor, G., and Lanis, R. (2016) Women on the board of directors and corporate tax aggressiveness in Australia, Accounting Research Journal, 29(3), 313-331.

Ullah, S., Akhtar, P., and Zaefarian, G. (2018) Dealing with endogeneity bias: The generalized method of moments (GMM) for panel data, Industrial Marketing Management, 71, 69-78. 
Wang, H., Xu, Z., and Huang, H. (2018) Operating Cash Flow, Earnings Management and Tax Aggressiveness: Evidence from Listed Companies in China, in International Conference on Management Science and Engineering Management (pp. 1069-1080), Springer, Cham.

Wilson, R. J. (2009) An examination of corporate tax shelter participants, The Accounting Review, 84(3), 969-999.

Yahya, F., and Ghazali, Z. B. (2017) Effectiveness of board governance and dividend policy as alignment mechanisms to firm performance and CEO compensation, Cogent Business \& Management, 4(1), 1398124.

Ye, D., Deng, J., Liu, Y., Szewczyk, S. H., and Chen, X. (2019) Does board gender diversity increase dividend payouts? Analysis of global evidence, Journal of Corporate Finance, 58, $1-26$.

Ying, T., Wright, B., and Huang, W. (2017). Ownership structure and tax aggressiveness of Chinese listed companies, International Journal of Accounting \& Information Management. 25(3), 313-332. 